\title{
Biosecurity and geospatial analysis of mycoplasma infections in poultry farms at Al-Jabal Al-Gharbi region of Libya
}

\author{
Abdulwahab Kammon ${ }^{1, *}$, Paolo Mulatti ${ }^{2}$, Monica Lorenzetto ${ }^{2}$, Nicola Ferre ${ }^{2}$, Monier Sharif ${ }^{3}$, Ibrahim Eldaghayes ${ }^{1}$ \\ and Abdunaser Dayhum ${ }^{1}$ \\ ${ }^{1}$ Faculty of Veterinary Medicine, University of Tripoli, P.O. Box 13662, Tripoli, Libya \\ ${ }^{2}$ Istituto Zooprofilattico Sperimentale delle Venezie, Viale dell'Universita, 10, Legnaro, Padova 35020, Italy \\ ${ }^{3}$ Faculty of Veterinary Medicine, University of Omar Al-Mukhtar, Albeida, Libya
}

\begin{abstract}
Geospatial database of farm locations and biosecurity measures are essential to control disease outbreaks. A study was conducted to establish geospatial database on poultry farms in Al-Jabal Al-Gharbi region of Libya, to evaluate the biosecurity level of each farm and to determine the seroprevalence of mycoplasma and its relation to biosecurity level. A field team of 7 Veterinarians belongs to the National Center of Animal Health was assigned for data recording and collection of blood samples. Personal information of the producers, geographical locations, biosecurity measures and description of the poultry farms were recorded. The total number of poultry farms in Al-Jabal Al-Gharbi Region is 461 farms distributed in 13 cities. Out of these, 102 broiler farms and one broiler breeder farm (10 houses) which were in operation during team visit were included in this study. Following collection of blood, sera were separated and tested by Enzyme-linked immunosorbent assay (ELISA) for the presence of antibodies against Mycoplasma (General antigen for M. gallisepticum and M. synoviae). The seroprevalence of Mycoplasma in the region was $28 \%$ (29 poultry farms out of 103 were infected). About 50\% (23 out of 47) of poultry farms located in Garian city were infected with Mycoplasma and one significant cluster of Mycoplasma infection in the city was identified. Low level of biosecurity was found in poultry farms of the region. Out of the 103 farms included, $63 \%$ of poultry houses has a ground of soil and $44 \%$ of them has uncoated walls which may influence the proper cleaning and disinfection. Almost $100 \%$ of the farms are at risk of exposure to diseases transmitted by wild birds such as avian influenza and Newcastle disease due to absence of wild birds control program. Although, $81 \%$ of the farms have entry restrictions, only $20 \%$ have disinfectants at entry which increase the risk of exposure to pathogens. The results of this study highlight the weakness points of biosecurity measures in poultry farms of Al-Jabal Al-Gharbi region and high seroprevalence of mycoplasma. Data collected in this study will assist the Veterinary authorities to apply effective disease control strategies.
\end{abstract}

Keywords: Biosecurity, Geospatial analysis, Mycoplasma, Poultry.

\section{Introduction}

The severe economic, social and public health consequences of infectious diseases in poultry require effective plans for rapid detection and response. Geospatial database of farm locations and biosecurity measures are essential to control disease outbreaks. Attributed farm locations are needed because many infectious disease mitigation strategies, such as culling or ring vaccination, explicitly rely on spatial relationships between susceptible animal population and pathogen reservoirs (Bruhn et al., 2012).

Biosecurity is the prevention or control of pathogenic microorganisms from contacting animal or human populations. In the context of modern poultry production, it is essentially keeping the birds separate from the agents causing the disease. Used properly, biosecurity will also minimize the effect of disease and contain the spread of disease, if found (Dorea et al., 2010).
Avian mycoplasmosis is caused by several pathogenic mycoplasmas of which Mycoplasma gallisepticum (MG) and M. synoviae (MS) are the most important; they are the only ones listed by the OIE. MG causes chronic respiratory disease of domestic poultry, especially in the presence of management stresses and/or other respiratory pathogens. Ms causes synovitis and/or airsacculitis. Infections of mycoplasma can yield significant losses in performance and associated economics to all sectors of the poultry industry worldwide (Evans et al., 2005).

In the 1999 outbreak of MG in North Carolina, Vaillancourt et al. (2000) found a direct connection between an MG-positive farm and a previous case when the MG-positive grower helped another grower who had MG and returned to his farm without changing clothing and boots which reflects a failure in biosecurity. Silva et al. (2015) found high seroprevalence rates of mycoplasma (MG \& MS) in 
backyard and commercial chickens which emphasize the need of keeping chicken flocks free from disease using effective biosafety systems.

There is lack of information on poultry industry in Libya in term of geospatial data. Moreover, to our knowledge, no detailed study has been carried out to determine the level of biosecurity that is practiced by poultry producers in Al-JabalAl-Gharbi region of Libya, and much less the relationship of such practices with mycoplasma infections. The present study was conducted for this reason.

\section{Data collection}

\section{Materials and Methods}

Prior to this study, there was no database on poultry production in this region. A field team of 7 Veterinarians belongs to the National Center of Animal Health was trained and assigned for collection of data using a questionnaire containing personal information of the producers, geographical information, information of the farm, biosecurity measures and some other questions on previous diseases and control measures adopted. Blood samples were collected for the detection of antibodies against MG and MS. One hundred and two broiler farms and one broiler breeder farm (10 houses) which are located in 10 cities were included in this study (Table 1).

Table 1. Number of the poultry farms evaluated for the level of biosecurity and mycoplasma seroprevalence.

\begin{tabular}{cc}
\hline City & Frequency \\
\hline Garian & 47 \\
Alasabaa & 3 \\
Kelaa & 1 \\
Yafrin & 11 \\
Rayaina & 12 \\
Zentan & 6 \\
Rujban & 2 \\
Alharaba & 1 \\
Nalut & 16 \\
Gadamis & 4 \\
\hline Total & 103 \\
\hline
\end{tabular}

All of these farms were in operation during visit and evaluated according to the level of biosecurity practice and the presence of antibodies against Mycoplasma taking into account the relationship between biosecurity level and Mycoplasma infection. Eleven biosecurity variables were included which are related to either proper cleaning and disinfection or protection of the flock from external pathogens. The biosecurity variables evaluated were shown in Table 2. Every variable was coded as good biosecurity practice ( $\operatorname{code}=$ $1)$ and bad biosecurity practice ( $\operatorname{code}=0)$.
Table 2. Names and description of biosecurity variables investigated.

\begin{tabular}{|c|c|c|}
\hline NO & $\begin{array}{c}\text { Biosecurity } \\
\text { variable (name) }\end{array}$ & Description (Code) \\
\hline 1 & GROUND & $\begin{array}{l}\text { Ground of the poultry house } \\
\text { (Soil }=0, \text { Concrete }=1)\end{array}$ \\
\hline 2 & WALL & $\begin{array}{l}\text { Walls of the poultry house } \\
\text { (uncoated brick=0, coated } \\
\text { brick=1) }\end{array}$ \\
\hline 3 & $\begin{array}{l}\text { DIS BETWEEN } \\
\text { FARMS }\end{array}$ & $\begin{array}{l}\text { Distance between farms } \\
(\leq 1000 \text { meter }=0,>1000 \\
\text { meter }=1)\end{array}$ \\
\hline 4 & $\begin{array}{l}\text { OTHER BIRD } \\
\text { SPECIES }\end{array}$ & $\begin{array}{l}\text { Other birds species in the } \\
\text { farm (yes }=0, n o=1)\end{array}$ \\
\hline 5 & $\begin{array}{l}\text { ENTRY } \\
\text { RESTRICTION }\end{array}$ & $\begin{array}{l}\text { The presence of a gate } \\
(\text { no }=0, \text { yes }=1)\end{array}$ \\
\hline 6 & $\begin{array}{l}\text { ENTRY } \\
\text { DISINFECTANTS }\end{array}$ & $\begin{array}{l}\text { Disinfectants at the gate for } \\
\text { cars }(\text { no }=0, \text { yes }=1)\end{array}$ \\
\hline 7 & $\begin{array}{l}\text { HOUSE } \\
\text { DISINFECTANTS }\end{array}$ & $\begin{array}{l}\text { Foot bath with disinfectants } \\
\text { in front of the house(s) } \\
(\mathrm{no}=0, \text { yes }=1)\end{array}$ \\
\hline 8 & $\begin{array}{l}\text { COVERALL } \\
\text { CLOTHS }\end{array}$ & $\begin{array}{l}\text { Presence of clothes for } \\
\text { visitors and workers ( } \mathrm{no}=0 \text {, } \\
\text { yes }=1 \text { ) }\end{array}$ \\
\hline 9 & BIRD DISPOSAL & $\begin{array}{l}\text { How dead birds are } \\
\text { disposed (thrown away=0, } \\
\text { burned and buried }=1 \text { ) }\end{array}$ \\
\hline 10 & $\begin{array}{l}\text { WILD BIRD } \\
\text { CONTROL }\end{array}$ & $\begin{array}{l}\text { Control of wild bird }(\mathrm{no}=0 \text {, } \\
\text { yes }=1)\end{array}$ \\
\hline 11 & $\begin{array}{l}\text { RODENTS } \\
\text { CONTROL }\end{array}$ & $\begin{array}{l}\text { Control of rodents }(\mathrm{no}=0 \text {, } \\
\text { yes }=1 \text { ) }\end{array}$ \\
\hline
\end{tabular}

\section{Serological analysis}

Twenty blood samples were collected from each poultry farm (each house) at the end of the production cycle. After collection, the blood samples were sent to the Veterinary Laboratory of the region. Sera were separated and tested by Enzyme-linked immunosorbent assay (ELISA) using Mycoplasma (MG-MS) commercial kit (Biochek ${ }^{\circledR}$, Netherlands).

\section{Spatial analysis}

In this study a map showing all seven branches (regions) of the National Center of Animal Health was designed using QGIS 2.8.1 software (http://www.qgis.org) (Fig. 1).

The poultry farms of Al-Jabal Al-Gharbi region were also shown on the map based on their coordinates.

The spatial aggregation of positive farms was investigated through a purely spatial scan statistic, using a Bernoulli probability model (Kulldorff, 1997), which is particularly suitable for presence/absence or positive/negative data.

Farms were considered positive based on at least one positive ELISA result. A cluster of positive farms was considered significant when the simulated P-value was $\leq 0.05$ (Dwass, 1957). The identified cluster was ranked on the basis of a likelihood function (Kulldorff and Nagarwalla, 1995; Kulldorff, 1997). 

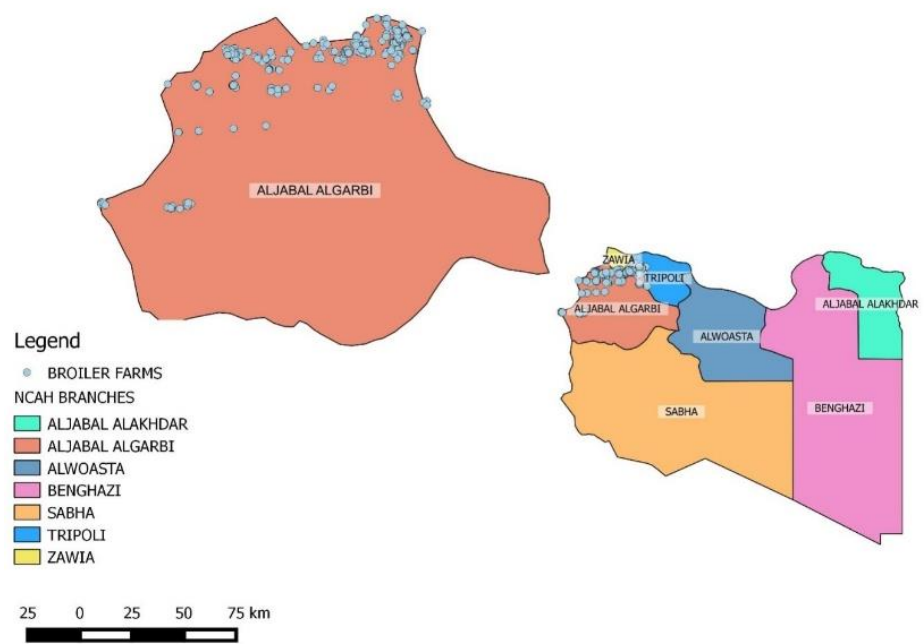

Fig. 1. A map showing the 7 branches of the National Center of Animal Health and poultry farms of Al-Jabal Al-Gharbi region.

Table 3. Number of poultry farms in different cities in Al-Jabal Al-Gharbi region.

\begin{tabular}{|c|c|c|c|c|c|c|}
\hline \multirow{2}{*}{ City } & \multicolumn{4}{|c|}{ No. of farms/housesat operation during study } & \multirow{2}{*}{$\begin{array}{l}\text { No. of empty farms (out of } \\
\text { operation during team visit) }\end{array}$} & \multirow{2}{*}{ Total } \\
\hline & Broilers & Layers & Breeders & Quails & & \\
\hline Nalut & 16 & 1 & 0 & 0 & 144 & 161 \\
\hline Garian & 60 & 3 & 1 & 1 & 59 & 124 \\
\hline Yafrin & 13 & 1 & 0 & 0 & 51 & 65 \\
\hline Rayaina & 17 & 1 & 0 & 0 & 27 & 45 \\
\hline Ruhaibat & 0 & 0 & 0 & 0 & 15 & 15 \\
\hline Gadamis & 11 & 0 & 0 & 0 & 1 & 12 \\
\hline Zentan & 9 & 0 & 0 & 0 & 2 & 11 \\
\hline Jadu & 0 & 0 & 0 & 0 & 7 & 7 \\
\hline Alasabaa & 5 & 0 & 0 & 0 & 2 & 7 \\
\hline Mezda & 0 & 0 & 0 & 0 & 6 & 6 \\
\hline Rujban & 3 & 0 & 0 & 0 & 1 & 4 \\
\hline Alharaba & 1 & 0 & 0 & 0 & 2 & 3 \\
\hline Kelaa & 1 & 0 & 0 & 0 & 0 & 1 \\
\hline Total & 136 & 6 & 1 & 1 & 317 & 461 \\
\hline
\end{tabular}

Table 4. Number and percentage of poultry farms showed good biosecurity practice at every biosecurity variable.

\begin{tabular}{|c|c|c|c|c|c|c|c|c|c|c|c|}
\hline $\begin{array}{l}\text { Biosecurity } \\
\text { variable }\end{array}$ & $\begin{array}{l}\text { Garian } \\
*_{n}=47\end{array}$ & $\begin{array}{c}\text { Alasabaa } \\
n=3\end{array}$ & $\begin{array}{c}\text { Kelaa } \\
\mathrm{n}=1\end{array}$ & $\begin{array}{c}\text { Yafrin } \\
\mathrm{n}=11\end{array}$ & $\begin{array}{c}\text { Rayaina } \\
\mathrm{n}=12\end{array}$ & $\begin{array}{c}\text { Zentan } \\
\mathrm{n}=6\end{array}$ & $\begin{array}{c}\begin{array}{c}\text { Rujban } \\
n=2\end{array} \\
\text { n }\end{array}$ & $\begin{array}{c}\text { Alharaba } \\
n=1\end{array}$ & $\begin{array}{l}\text { Nalut } \\
\mathrm{n}=16\end{array}$ & $\begin{array}{c}\text { Gadamis } \\
\mathrm{n}=4\end{array}$ & $\begin{array}{c}\text { Total } \\
\mathrm{n}=103\end{array}$ \\
\hline Ground & 20 & 0 & 0 & 2 & 6 & 3 & 0 & 1 & 4 & 2 & $38(37 \%)$ \\
\hline Wall & 37 & 1 & 0 & 5 & 8 & 1 & 0 & 0 & 6 & 0 & $58(56 \%)$ \\
\hline $\begin{array}{l}\text { Dis. Between } \\
\text { farms }\end{array}$ & 13 & 3 & 1 & 3 & 1 & 6 & 1 & 1 & 8 & 2 & $39(38 \%)$ \\
\hline $\begin{array}{l}\text { Other bird } \\
\text { species }\end{array}$ & 44 & 3 & 1 & 11 & 10 & 6 & 2 & 1 & 12 & 4 & $94(91 \%)$ \\
\hline $\begin{array}{l}\text { Entry } \\
\text { restriction }\end{array}$ & 45 & 3 & 1 & 2 & 12 & 6 & 2 & 1 & 11 & 0 & $83(81 \%)$ \\
\hline $\begin{array}{l}\text { Entry } \\
\text { disinfectants }\end{array}$ & 9 & 0 & 0 & 5 & 1 & 1 & 0 & 0 & 5 & 0 & $21(20 \%)$ \\
\hline $\begin{array}{l}\text { House } \\
\text { disinfectants }\end{array}$ & 45 & 3 & 1 & 10 & 12 & 6 & 2 & 1 & 16 & 4 & $100(97 \%)$ \\
\hline $\begin{array}{l}\text { Coverall } \\
\text { cloths }\end{array}$ & 5 & 0 & 0 & 5 & 0 & 5 & 0 & 1 & 1 & 0 & $17(17 \%)$ \\
\hline Bird disposal & 14 & 0 & 1 & 4 & 2 & 5 & 1 & 0 & 13 & 4 & $44(43 \%)$ \\
\hline $\begin{array}{l}\text { Wild bird } \\
\text { control }\end{array}$ & 1 & 0 & 0 & 0 & 0 & 0 & 0 & 0 & 0 & 0 & $1(0.97 \%)$ \\
\hline $\begin{array}{l}\text { Rodents } \\
\text { control }\end{array}$ & 3 & 0 & 0 & 9 & 6 & 1 & 1 & 0 & 2 & 0 & $22(21 \%)$ \\
\hline
\end{tabular}

$* \mathrm{n}=$ number of poultry farms that participated. 
The data were handled bySaTScanTM version 9.1.1 (http://www.satscan.org), while the output was visualised in $\mathrm{ESRI}^{\mathrm{TM}}$ ArcMap®version 10.1 (http://www.esri.com/).

\section{Results and Discussion}

The total number of poultry farms in Al-Jabal AlGharbi Region is 461 farms distributed in 13 cities (Table 3). Poultry farms showed low level of biosecurity especially the ground of the houses, distance between farms, the presence of disinfectants at the farm entry, the use of coverall cloths, disposal of dead birds and control of wild birds and rodents (Table 4). $63 \%$ of poultry houses has a ground of soil and $44 \%$ of them has uncoated walls which may influence the proper cleaning and disinfection. Almost $100 \%$ of the farms are at risk of exposure to diseases transmitted by wild birds such as avian influenza and Newcastle disease due to absence of wild birds control program (Keawcharoen et al., 2011). Although, 81\% of the farms have entry restrictions, only $20 \%$ have disinfectants at entry which increase the risk of exposure to pathogens that may be transmitted by vehicles carrying feed, day old chicks, etc,. Biosecurity and biosurveillance measures have been largely successful at minimizing MG outbreaks among the breeding stock of the turkey and chicken industries (Evans et al., 2005).

Table 5 presenting the number of poultry farms infected with Mycoplasma. The prevalence of Mycoplasma (MG-MS) in the region was $28 \%$ (29 poultry farms out of 103 were infected).

Table 5. Number of poultry farms infected with Mycoplasma.

\begin{tabular}{lc}
\hline City & MG-MS** \\
\hline Garian $(* n=47)$ & 23 \\
Alasabaa $(n=3)$ & 0 \\
Kelaa $(\mathrm{n}=1)$ & 1 \\
Yafrin $(\mathrm{n}=11)$ & 1 \\
Rayaina $(\mathrm{n}=12)$ & 0 \\
Zentan $(\mathrm{n}=6)$ & 1 \\
Rujban $(\mathrm{n}=2)$ & 0 \\
Alharaba $(\mathrm{n}=1)$ & 1 \\
Nalut $(\mathrm{n}=16)$ & 1 \\
Gadamis $(\mathrm{n}=4)$ & 1 \\
\hline Total $(\mathrm{n}=103)$ & $29(28 \%)$ \\
*n= number of poultry farms that participated. \\
**MG-MS= Mycoplasma Gallisepticum and Mycoplasma Synovie \\
(Mycoplasma general antigen).
\end{tabular}

About 50\% (23 out of 47) of poultry farms located in Garian city were infected with Mycoplasma (MG-MS). This may due to the extensive production in the city. This study showed presence of other bird species mainly backyard chickens in $94 \%$ of the poultry farms (Table 4).

Backyard chickens could play important role in mycoplasma spread. Buchala et al. (2006) tested 15 free range chicken farms and found seroprevalence of $73 \%$ for $\mathrm{MG}$ and $100 \%$ for MS.

Pereira (2005), in a study on the prevalence of antibodies against MG and MS in 160 backyard chickens in Uberlândia, found that 102 (63.8\%) were positive for MG. In the 1999 outbreak of MG in North Carolina, Vaillancourt et al. (2000) found a direct connection between an MG-positive farm and a previous case when the MG-positive grower helped another grower who had MG and returned to his farm without changing clothing and boots which reflects a failure in biosecurity. This may indicate that birds reared in farms where biosecurity programs are implemented are less contaminated than those reared in environments with no biosecurity measures (Silva et al., 2015).

Spatial analysis scanning for clusters with high rates using the Bernoulli model was conducted using SatScan Software. Geographical localization of Mycoplasma infection clusters in Al-Jabal Al-Gharbi region are shown in Figure 2.

Spatial analysis identified one significant cluster of Mycoplasma infection ( $\mathrm{P}<0.01)$ (Fig. 2; Table 6). This cluster is mostly located within Garian's administration borders.

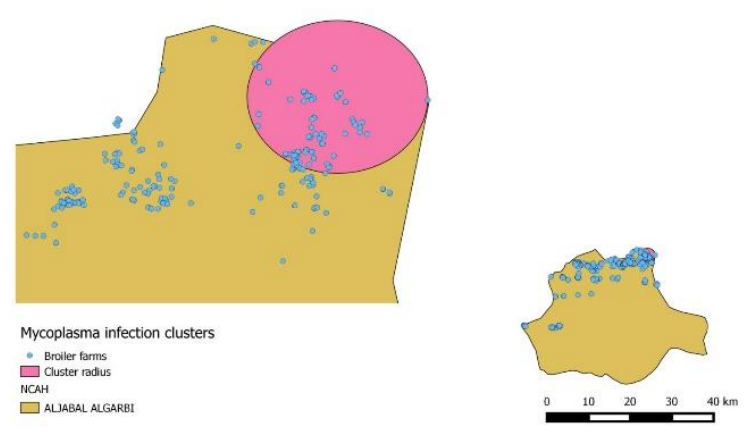

Fig. 2. Geographical localization of Mycoplasma infection clusters in Al-Jabal Al-Gharbi region.

Table 6. Characteristics of Mycoplasma cluster.

\begin{tabular}{cccccc}
\hline $\begin{array}{c}\text { Cluster Radius } \\
\text { ID }\end{array}$ & $\begin{array}{c}\text { No. of } \\
\text { farms }\end{array}$ & $\begin{array}{c}\text { No. of } \\
\text { cases } \\
\text { included }\end{array}$ & $\begin{array}{c}\text { No. of } \\
\text { cases } \\
\text { observed }\end{array}$ & P-value \\
\hline 1 & 21.52 & 29 & 18 & 2.14 & 0.0013 \\
\hline
\end{tabular}

Geographic information system (GIS) and spatial analyses constitute a useful approach that supports the generation of hypotheses on drivers for disease diffusion based (Pfeiffer et al., 2008). This study showed that all poultry farms of Al-Jabal Al-Gharbi region had bad biosecurity practice which may be a good reason for wide spread of mycoplasma infections. However, there is still a possibility of vertical transmission of mycoplasma from infected parents to their progeny. 
The results of this study highlight the weakness points of biosecurity measures in poultry farms of Al-Jabal AlGharbi region. The seroprevalence rates of mycoplasma found in the present study emphasize the need of keeping chicken flocks free from disease using effective biosecurity system. Veterinary authorities has to inforce the application of biosecurity measures to improve birds' health and welfare.

Training of producers on the importance of biosecurity and its applications is of great value. This may be achieved by conducting seminars, using media and leaflets.

\section{Conflict of interest}

The authors declare that there is no conflict of interest.

\section{Acknowledgments}

The authors acknowledge the assistance of the Veterinarians and Veterinary Laboratory Staff of AlJabal Al-Gharbi region for collection of data and testing of blood samples.

\section{References}

Bruhn, M.C., Munoz, B., Cajka, J., Smith, G., Curry, R.J., Wagener, D.K., and Wheaton, W.D. 2012. Synthesized Population Databases: A Geospatial Database of US Poultry Farms. Methods Rep. RTI Press. 2012 Jan 1; MR-0023-1201, 1-24.

Buchala, F.G., Ishizuka, M.M., Mathias, L.A., Berchieri Júnior, A.G.M., Cardoso, A.L.S.P., Tessari, E.N.C. and Kanashiro, A.M.I. 2006. Detecção de resposta sorológica contra Mycoplasma em aves de criatórios de "fundo de quintal" próximos a explorações comerciais do estado de São Paulo. Arquivos do Instituto Biológico 73(2), 143-148.

Dorea, F.C., Berghaus, R., Hofacre, C. and Cole, D.J. 2010. Survey of Biosecurity Protocols and Practices Adopted by Growers on Commercial Poultry Farms in Georgia, U. S. A. Avian Dis. 54, 1007-1015.

Dwass, M. 1957. Modified randomization tests for nonparametric hypotheses. Ann. Math. Stat. 28,
$181-187$

Evans, J.D., Leigh, S.A., Branton, S.L., Collier, S.D., Pharr, G.T. and Bearson, S.M.D. 2005. Mycoplasma gallisepticum: Currentand Developing Means to Controlthe Avian Pathogen. J. Appl. Poult. Res. 14, 757-763.

Keawcharoen, J., van den Broek, J., Bouma, A., Tiensin, T., Osterhaus, A.D. and Heesterbeek, H. 2011. Wild Birds and Increased Transmission of Highly Pathogenic Avian Influenza (H5N1) among Poultry, Thailand. Emerg. Infect. Dis. 17(6), 10161022.

Kulldorff, M. 1997. A spatial scan statistic. Commun. Stat. Theory Meth. 26, 1481-1496.

Kulldorff, M. and Nagarwalla, N. 1995. Spatial disease clusters: detection and inference. Stat. Med. 14, 799-810.

Pereira, M.S. 2005. Prevalência de anticorpos contra Mycoplasma gallisepticum, Mycoplasma synoviae e Salmonella pullorum e identificação bacteriológica de Salmonella spp. em galinhas "caipiras" no município de Uberlândia [Monografia]. Uberlândia (MG): Universidade Federal de Uberlândia.

Pfeiffer, D.U., Robinson, T.P., Stevenson, M., Stevens, K.B., Rogers, D.J. and Clements, A.C.A. 2008. Spatial analysis in epidemiology. Oxford University Press, pp: 142.

Silva, C.B.C., Chagas, W.F., Santos, R.F., Gomes, L.R., Ganda, M.R. and Lima, A.M.C. 2015. Seroprevalence of Salmonella and Mycoplasma in Commercial Broilers, Backyard Chickens, and Spent Hens in the Region of Triângulo Mineiro, State of Minas Gerais, Brazil. Brazilian J. Poult. Sci. 17(1), 57-62.

Vaillancourt, J.-P., Martinez, A., Smith, C. and Ley, D. 2000. The epidemiology of Mycoplasma gallisepticumin North Carolina. In: Proc. 35 National Meeting on Poultry Health and Processing, Ocean City, MD, pp: 34-36. 